\title{
Surveillance for Salmonella in migratory, feral and zoo birds
}

Azhar G. Shalaby; Erfan A. M. and Soad A. Nasef

Reference lab for Veterinary Quality Control on Poultry Production (Animal Health research institute)

\begin{abstract}
In a surveillance targeting different birds communities, 237 cloacal swabs and intestinal samples from 39 different species of wild birds from different sources were examined bacteriologically for Salmonella. 32 samples were positive for Salmonella spp., with an incidence of $13.5 \%$. Migratory birds had the highest incidence with a 28.26 percentage. The incidence in free living birds was somewhat lower (18.57\%). While the Zoo birds had the lowest incidence $(4.96 \%)$. Serotyping of the isolates revealed 6 different serotypes [Salmonella Typhimurium, Salmonella Rissen, Salmonella Regent, Salmonella Doncaster, Salmonella Curacao, Salmonella IIIb group (O65) and untyped Salmonella] . Salmonella Typhimurium represented $40.63 \%$ of the isolated serotypes. In vitro antibiogram test was performed for the 2 strains isolated from Zoo birds. Salmonella Curacao was sensitive to most of the utilized antimicrobial agents. However Salmonella IIIb group (O65) had surprising results as it was resistant to 10 out of the 11 applied antibiotics. 26 serum samples were examined by tube agglutination test using $S$. Typhimurium antigen where 15 samples were positive. PCR technique was done on 30 samples to assess the power of two different isolation enrichments[Rappaport vassiliadis (RV) and buffered peptone water (BPW)] in comparison to that of the standard microbioligical techniques (SMT). The detection percentages of RV-PCR, BPW-PCR and SMT was 66.7\%, 46.7\%, and $13.3 \%$, respectively.
\end{abstract}

Key words. Salmonella, feral, Gallinarum which cause fowl migratory, zoo, PCR, agglutination.

\section{Introduction:}

Public heath can be severely affected by wild birds because they can be infected by different disease agents especially Salmonella. They have been infected with different Salmonella serovars such as Salmonella pullorum which cause Pullorum disease and Salmonella typhoid. But, wild birds are more commonly infected by the variant of Salmonellae that are collectively referred to as paratyphoid forms, of which Salmonella Typhimurium is a predominant representative (Friend and Franson, 1988).

Monitoring the health of the birds and its relation to human is so important through isolation and identification of Salmonella as well 
as detection of the common antimicrobial drugs which are required for treatment of birds suffering from salmonellosis (Olivera et al, 2006).

There was an alarming increase in wild birds' mortality; the species affected were primarily Pine siskins, Purple finches, House sparrows and all of the examined birds died due to infection with Salmonella Typhimurium (Bowes, 1993).

The agglutination tests have been used for detecting antibodies to various paratyphoid Salmonellae especially $S$. Typhimurium (Swayne et al, 1998).

Serological tests are developed for the diagnosis of Salmonella infection in animals and birds. These tests are normally designed to detect a limited range of Salmonella serovars. Serum agglutination test (SAT) is used successfully for over 50 years for identification of infected flock; tube agglutination test (TAT) is the method of choice for diagnostic purposes for samples from all species of animals and birds (OIE, 2004).

PCR represents a major advance in diagnostic methods in terms of speed and sensitivity (Freschi et al, 2005).

The aim of the work was to study the incidence of Salmonellae in wild birds of different species (migratory birds, Zoo birds and free living birds), serotyping of the isolates of Salmonella by slide agglutination test using poly and monovalent antisera, application of antimicrobial susceptibility test against the Salmonella isolates from Zoo birds species. Detection of Salmonella Typhimurium antibodies among Zoo birds using tube agglutination test was applied to differentiate the infected from carrier birds. Amplification of the (invA) gene PCR to confirm the identification of Salmonella spp. and finally to evaluate PCR under different enrichments for Salmonella isolates.

\section{Material and Methods:}

Sampling. A total of 237 different samples from 39 different wild birds species were collected to be examined. These were 209 cloacal swabs, 28 intestinal samples. Thirty five drag swabs (13 from feral birds houses and 22 from zoo birds) were collected. Also, 26 serum samples were collected from zoo birds only.

Isolation and identification of Salmonella. ISO 6579 (2002) was used for isolation and identification of Salmonella.

Salmonella Serotyping. The organisms were serotyped according to Kauffmann and DasKauffmann (2001) using $\mathrm{O}$ and $\mathrm{H}$ antisera (Mast assure Co.). Antimicrobial susceptibility test using the disk diffusion technique was applied according to (Cruickshank et al, 1975).

Tube agglutination test was done for detection of Salmonella Typhimurium antibodies among the 
examined Zoo birds (Swayne et al, 1998).

These antigens which were used in the tube agglutination test were kindly obtained from Institute of Serum and Vaccine Production, Abassia, Egypt.

Salmonella PCR. Extraction of Salmonella DNA was done by boiling method (Croci, 2004), and amplification of invA gene was done according to Olivera et al (2003). Initial denaturation at $94^{\circ} \mathrm{C}$ for $5 \mathrm{~min}$, followed by 35 cycles of denaturation at $94^{\circ} \mathrm{C}$ for $1 \mathrm{~s}$, annealing at $55^{\circ} \mathrm{C}$ for $1 \mathrm{~s}$, extension at $72^{\circ} \mathrm{C}$ for $21 \mathrm{~s}$ and a final extension at $72^{\circ} \mathrm{C}$ for $7 \mathrm{~min}$ was applied in Biometra T3000 thermocycler.

\section{Results:}

Incidence of Salmonella from different bird groups.

Salmonella spp. was identified by culture characters as well as the biochemical and serological tests. Most isolated Salmonella spp. were from migratory birds followed by free living birds then Zoo birds. The results revealed that on examination of 237 samples collected from 39 wild bird species, Salmonella species were isolated with an incidence of $13.5 \%$. Table (1).

The incidence of Salmonella species from migratory birds was $28.26 \%$ (13/46), While, it was $4.96 \%$ (6/121) from Zoo birds and by examination of free living birds (feral birds), the incidence of
Salmonella was $18.57 \%$ (13/70). Table (1).

Incidence of Salmonella from Zoo birds.

Positive cases of Salmonella species were recorded with an incidence of $4.96 \%$ (6/121) from 22 examined species of Zoo birds. Table (4).

\section{Salmonella Serotyping:}

Salmonella Typhimurium was the most isolated strain (13/32) with a percentage of $40.6 \%$ followed by Salmonella Doncaster (5/32) with a percentage of $15.63 \%$, Both Salmonella Curacao and Salmonella Rissen (4/32) with percentage of $12.5 \%$ each, Salmonella Regent (3/32) with a percentage of $9.37 \%$, Salmonella IIIb (2/32) with a percentage of $6.25 \%$ and untyped one $(1 / 32)$ with a percentage of $3.125 \%$.

Antibiotic susceptibility testing was done for the 2 isolated strains from the Zoo birds [ Salmonella Curacao and Salmonella IIIb (group O65)]. Salmonella Curacao was sensitive to chloramphenicol, colistin, streptomycin, tetracycline, nalidixic acid erythromycin and danofloxacin. This strain was intermediately sensitive to doxycycline and gentamicin, while, it was resistant to ampicillin, neomycin and penicillin $\mathrm{G}$ as shown in Table (7).

On the other hand, Salmonella IIIb (group O65), was only sensitive to danofloxacin and resistant to the rest of the antimicrobial agents (multidrug resistant strain). 
Result of Salmonella isolation from drag swabs.

All the samples were negative for Salmonella spp. either from the (13) feral Pigeon houses or the 24 Zoo bird houses.

Tube agglutination test. From the26 serum samples examined from the 6 Zoo bird species, 15 sera were positive (suspected to be positive carriers) with $57.6 \%$.
PCR results. After a comparison between SMT and PCR using enriched samples with BPW and $\mathrm{RV}$, it was revealed that Salmonella species were detected in the percentages of $13.3 \%$, while they were detected by BPW-PCR and RV-PCR with the percentages of $46.7 \%$ and $66.7 \%$, respectively as shown in Table (9).

Table (1): Incidence of Salmonella species isolated from cloacal swabs and intestinal samples of wild birds.

\begin{tabular}{|c|c|c|c|c|c|}
\hline \multirow{2}{*}{$\begin{array}{c}\text { Different } \\
\text { wild } \\
\text { Birds }\end{array}$} & \multicolumn{2}{|c|}{$\begin{array}{c}\text { No. of examined } \\
\text { samples }\end{array}$} & \multirow{2}{*}{$\begin{array}{c}\text { No. of wild } \\
\text { bird species }\end{array}$} & \multicolumn{2}{|c|}{$\begin{array}{c}\text { Incidence of } \\
\text { Salmonella isolation }\end{array}$} \\
\cline { 2 - 5 } & Live & Dead & & No. & \% \\
\hline Migratory & 25 & 21 & 8 & 13 & 28.26 \\
\hline Zoo birds & 121 & 0 & 24 & 6 & 4.96 \\
\hline Feral & 63 & 7 & 7 & 13 & 18.57 \\
\hline Total & \multicolumn{2}{|c|}{237} & 39 & 32 & 13.5 \\
\hline
\end{tabular}

Table (2) Incidence of Salmonella species isolated from live migratory birds.

\begin{tabular}{|c|c|c|c|}
\hline \multirow{2}{*}{ Species } & \multirow{2}{*}{$\begin{array}{c}\text { No. of examined cloacal } \\
\text { Swabs samples }\end{array}$} & \multicolumn{2}{|c|}{$\begin{array}{c}\text { Incidence of Salmonella } \\
\text { isolation }\end{array}$} \\
\cline { 3 - 4 } & & No. & $\%$ \\
\hline Guinea fowl & 9 & 0 & 0.00 \\
\hline Common pintail & 4 & 3 & 75 \\
\hline Common coot & 5 & 1 & 20 \\
\hline Shoveler & 5 & 0 & 0 \\
\hline Little stint & 2 & 0 & 0 \\
\hline Total & 25 & 4 & 16 \\
\hline
\end{tabular}


Table (3) Incidence of Salmonella species isolated from dead migratory birds.

\begin{tabular}{|c|c|c|c|}
\hline \multirow{2}{*}{ Species } & \multirow{2}{*}{$\begin{array}{c}\text { No. of examined } \\
\text { intestinal content samples }\end{array}$} & \multicolumn{2}{|c|}{$\begin{array}{c}\text { Incidence of } \\
\text { Salmonella isolation }\end{array}$} \\
\cline { 3 - 4 } & & No. & \% \\
\hline Green winged duck & 9 & 7 & 77.78 \\
\hline Water fowl & 10 & 1 & 10.00 \\
\hline Sheldrake & 2 & 1 & 50.00 \\
\hline Total & 21 & 9 & 42.86 \\
\hline
\end{tabular}

Table (4): Incidence of Salmonella from Zoo birds.

\begin{tabular}{|c|c|c|c|}
\hline \multirow[t]{2}{*}{ Species of Zoo birds } & \multirow{2}{*}{$\begin{array}{l}\text { No. of examined cloacal swabs } \\
\text { samples }\end{array}$} & \multicolumn{2}{|c|}{$\begin{array}{c}\text { Incidence of Salmonella } \\
\text { isolation }\end{array}$} \\
\hline & & No. & $\%$ \\
\hline \multicolumn{4}{|c|}{ Galliformes: } \\
\hline Common pea fowl & 10 & 0 & 0.00 \\
\hline White pea fowl & 10 & 0 & 0.00 \\
\hline Helmented guinea fowl & 10 & 0 & 0.00 \\
\hline Golden pheasant & 2 & 0 & 0.00 \\
\hline Mongolian pheasant & 2 & 0 & 0.00 \\
\hline Silver pheasant & 2 & 0 & 0.00 \\
\hline Spotted sand grouse & 3 & 0 & 0.00 \\
\hline \multicolumn{4}{|c|}{ Anseriformes: } \\
\hline Mallard duck & 10 & 0 & 0.00 \\
\hline Grey Chinese goose & 9 & 2 & 22.2 \\
\hline Egyptian goose & 3 & 0 & 0.00 \\
\hline Pick duck & 3 & 0 & 0.00 \\
\hline Wild turkey & 5 & 0 & 0.00 \\
\hline \multicolumn{4}{|c|}{ Passeriformes: } \\
\hline Grey and white Zebra finches & 4 & 0 & 0.00 \\
\hline \multicolumn{4}{|c|}{ Psittaciformes: } \\
\hline Peach faced rosy & 6 & 0 & 0.00 \\
\hline African grey parrot & 4 & 2 & 50.0 \\
\hline Ornate lorry & 2 & 0 & 0.00 \\
\hline Pied cockatiel & 4 & 2 & 50.0 \\
\hline Blue and yellow marcow & 4 & 0 & 0.00 \\
\hline \multicolumn{4}{|c|}{ Ciconiiformes: } \\
\hline White stork & 2 & 0 & 0.00 \\
\hline \multicolumn{4}{|c|}{ Phoenicopterformes: } \\
\hline Greater flamingo & 3 & 0 & 0.00 \\
\hline \multicolumn{4}{|c|}{ Strathionformes: } \\
\hline Ostrich & 6 & 0 & 0.00 \\
\hline Emu & 4 & 0 & 0.00 \\
\hline \multicolumn{4}{|c|}{ Pelicaniformes: } \\
\hline White pelican & 8 & 0 & 0.00 \\
\hline \multicolumn{4}{|c|}{ Columbiformes: } \\
\hline Fantail pigeon & 5 & 0 & 0.00 \\
\hline Total & 121 & 6 & 4.96 \\
\hline
\end{tabular}


Table (5). Incidence of Salmonella species isolated from the different examined live feral birds.

\begin{tabular}{|c|c|c|c|}
\hline \multirow{2}{*}{ Species } & \multirow{2}{*}{$\begin{array}{c}\text { No. of examined } \\
\text { cloacal swabs samples }\end{array}$} & \multicolumn{2}{|c|}{$\begin{array}{c}\text { Incidence of } \\
\text { Salmonella isolation }\end{array}$} \\
\cline { 3 - 4 } & 14 & 0 & 0.0 \\
\hline Quail & 5 & 8 & 0 \\
\hline Rook & 14 & 8 & 57.14 \\
\hline Kestrel & 2 & 0 & 0 \\
\hline Falcon & 20 & 4 & 20 \\
\hline Pigeon & 4 & 0 & 0 \\
\hline Sparrow & 4 & 0 & 0 \\
\hline Parrots & 63 & 12 & 19.04 \\
\hline Total & & &
\end{tabular}

Table (6): Incidence of Salmonella species isolated from the different examined dead feral birds.

\begin{tabular}{|c|c|c|c|}
\hline \multirow{2}{*}{ Species } & \multirow{2}{*}{$\begin{array}{c}\text { No. of examined intestinal } \\
\text { content samples }\end{array}$} & \multicolumn{2}{|c|}{$\begin{array}{c}\text { Incidence of Salmonella } \\
\text { isolation }\end{array}$} \\
\cline { 3 - 4 } & & No. & $\%$ \\
\hline Pigeon & 3 & 0 & 0 \\
\hline Parrots & 3 & 1 & 33.3 \\
\hline Sparrow & 1 & 0 & 0 \\
\hline Total & 7 & 1 & 14.3 \\
\hline
\end{tabular}

Table (7): Results of antibiotic sensitivity testing for the two isolates of Salmonella from Zoo birds.

\begin{tabular}{|c|c|c|}
\hline \multirow{2}{*}{ Antimicrobial agent } & S. Curacao & S. IIIb (group O65) \\
\cline { 2 - 3 } & Susceptibility & Susceptibility \\
\hline Ampicillin (Amp) $10 \mu \mathrm{g}$ & $\mathrm{R}$ & $\mathrm{R}$ \\
\hline Chloramphenicol (C) $30 \mu \mathrm{g}$ & $\mathrm{S}$ & $\mathrm{R}$ \\
\hline Colistin (CT) $10 \mu \mathrm{g}$ & $\mathrm{S}$ & $\mathrm{R}$ \\
\hline Danofloxacin (DFX) $5 \mathrm{mg}$ & $\mathrm{S}$ & $\mathrm{S}$ \\
\hline Doxycycline (DO) $30 \mu \mathrm{g}$ & $\mathrm{I}$ & $\mathrm{R}$ \\
\hline Erythromycin (E) $15 \mu \mathrm{g}$ & $\mathrm{S}$ & $\mathrm{R}$ \\
\hline Gentamicin (GM) $10 \mu \mathrm{g}$ & $\mathrm{I}$ & $\mathrm{R}$ \\
\hline Nalidixic acid (NA) $30 \mu \mathrm{g}$ & $\mathrm{S}$ & $\mathrm{R}$ \\
\hline Neomycin (N) $30 \mu \mathrm{g}$ & $\mathrm{R}$ & $\mathrm{R}$ \\
\hline Penicillin G (P) $10 \mu \mathrm{g}$ & $\mathrm{R}$ & $\mathrm{R}$ \\
\hline Streptomycin (Strep) $10 \mu \mathrm{g}$ & $\mathrm{S}$ & $\mathrm{R}$ \\
\hline Tetracycline $30 \mu \mathrm{g}$ & $\mathrm{S}$ & \\
\hline
\end{tabular}

S: sensitive I: intermediate R: resistant 
Table (8): Serological identification of Salmonella Typhimurium by tube agglutination test.

\begin{tabular}{|c|c|c|}
\hline Species & $\begin{array}{c}\text { No of examined } \\
\text { samples }\end{array}$ & $\begin{array}{c}\text { Results of S. Typhimurium } \\
\text { antigen (TAT) titer }\end{array}$ \\
\hline Helmented Guinea fowl & 4 & $2(+\mathrm{ve})$ \\
\hline White Guinea fowl & 2 & $1(+\mathrm{ve})$ \\
\hline Mallard duck & 4 & $4(+\mathrm{ve})$ \\
\hline Fantail pigeon & 4 & $2(+\mathrm{ve})$ \\
\hline White pea fowl & 4 & $1(+\mathrm{ve})$ \\
\hline Common pea fowl & 5 & $2(+\mathrm{ve})$ \\
\hline Grey Chinese goose & 3 & $3(+\mathrm{ve})$ \\
\hline Total & 26 & 15 \\
\hline
\end{tabular}

$1 / 25$ or 1/50 was considered as $+v e$ carrier bird for S. Typhimurium.

Table (9): Comparison between standard microbiological techniques (SMT), $B P W-P C R$ and RV-PCR for detection of Salmonella among different wild birds from different sources.

\begin{tabular}{|c|c|c|c|}
\hline Samples sources & SMT & BP PCR & RV PCR \\
\hline \multicolumn{4}{|c|}{ Migratory birds } \\
\hline Green winged duck (1) & +ve & $+\mathrm{ve}$ & $+\mathrm{ve}$ \\
\hline Green winged duck (2) & -ve & $-\mathrm{ve}$ & $+\mathrm{ve}$ \\
\hline Sheldrake & $-\mathrm{ve}$ & -ve & $+\mathrm{ve}$ \\
\hline Shoveler & -ve & -ve & -ve \\
\hline Guinea fowl & -ve & -ve & -ve \\
\hline \multicolumn{4}{|c|}{ Zoo birds } \\
\hline Helminted Guinea fowl & $-\mathrm{ve}$ & $+\mathrm{ve}$ & $+\mathrm{ve}$ \\
\hline Mallard duck & $-\mathrm{ve}$ & $+\mathrm{ve}$ & $+\mathrm{ve}$ \\
\hline Common pea fowl & -ve & -ve & $-\mathrm{ve}$ \\
\hline Grey Chinese goose & -ve & $+\mathrm{ve}$ & $+\mathrm{ve}$ \\
\hline Blue and yellow marcow & $-\mathrm{ve}$ & -ve & $+\mathrm{ve}$ \\
\hline \multicolumn{4}{|c|}{ Feral birds } \\
\hline Kestrel & $-\mathrm{ve}$ & -ve & -ve \\
\hline Sparrow & -ve & $+\mathrm{ve}$ & $+\mathrm{ve}$ \\
\hline Pigeon (1) & -ve & $+\mathrm{ve}$ & $+\mathrm{ve}$ \\
\hline Pigeon (2) & $+\mathrm{ve}$ & -ve & $+\mathrm{ve}$ \\
\hline Pigeon (3) & -ve & -ve & -ve \\
\hline Total Positive & 2 & 6 & 10 \\
\hline Percent $=\%$ & $13.3 \%$ & $46.7 \%$ & $66.7 \%$ \\
\hline
\end{tabular}

The percent was calculated in relation to the total number of samples (15). 


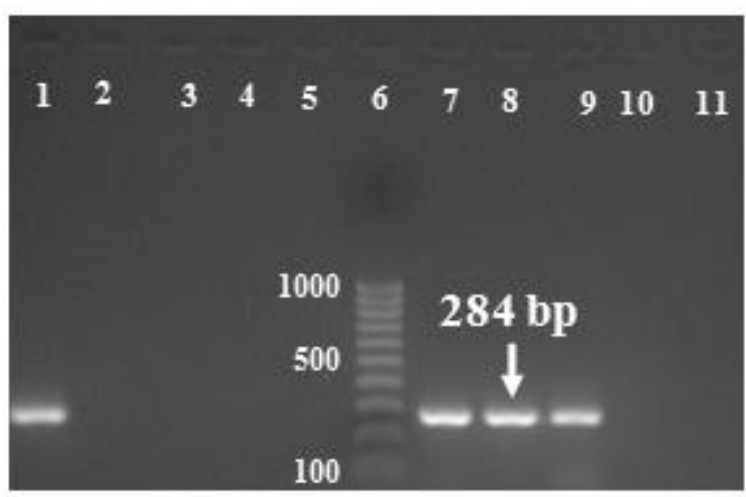

Photo. (1) Agarose gel electrophoresis showing the result of PCR for detection of Salmonella isolated from migratory birds.

Lanes 1-5 represent the Buffer peptone enrichment samples obtained from Green winged duck 1, Green winged duck 2, Sheldrake, Shoveler and Guinea fowl, respectively. Lane 6 represents the molecular weight marker (100 bp ladder, fermentas). Lanes 7-11 represent the RV enrichment samples obtained from the same species respectively. Positive amplification of 284 bp of the invA gene of Salmonella was recorded in lanes 1, 7, 8 and 9.

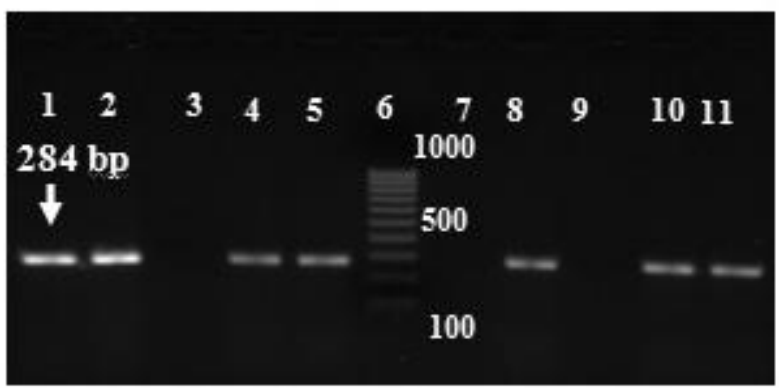

Photo. (2) Agarose gel electrophoresis showing the result of PCR for detection of Salmonella isolated from Zoo birds.

Lanes 1-5 represent the RV enrichment sample obtained from Helmented Guniea fowl, Mallard duck, Common pea fowl, Grey Chinese goose and Blue and yellow marcow, respectively. Lane 6 represents the molecular weight marker (100 bp ladder, fermentas). Lanes 7-11 represent the Buffer peptone enrichment sample obtained from the same species respectively. Positive amplification of $284 \mathrm{bp}$ of the invA gene of Salmonella was recorded in lanes $1,2,4,5,8,10$ and 11 . 


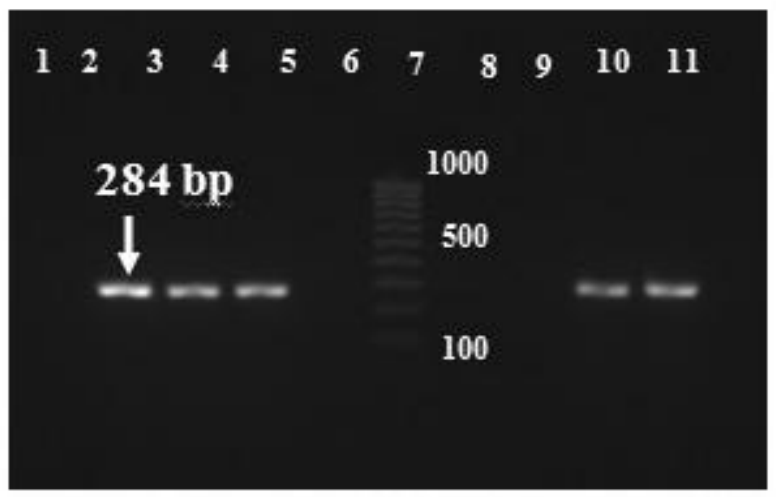

Photo. (3) Agarose gel electrophoresis showing the result of PCR for Salmonella isolated from feral birds.

Lanes 1-5 represent the RV enrichment samples obtained from Kestrel, Sparrow, Pigeon 1, Pigeon 2 and Pigeon 3, respectively. Lane 7 represents the molecular weight marker (100 bp ladder, fermentas). Lanes 6 represents the Buffer peptone enrichment samples obtained from Kestrel. Lanes 8 and 9 represent the same as lane 6 but for Pigeon 2 and Pigeon 3, respectively. Lanes 10 and 11 represent the same as lane 6 but for Sparrow and Pigeon 1, respectively. Positive amplification of the $284 \mathrm{bp}$ for invA gene of Salmonella was recorded in lanes 2, 3, 4, 10 and 11.

negative Positive

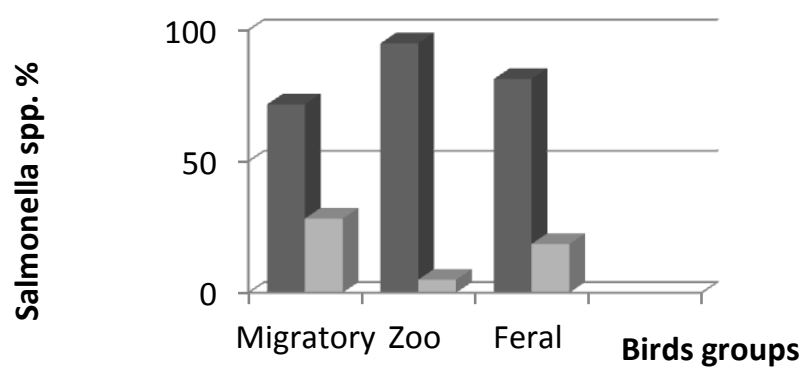

Fig. (1): Salmonella incidence in different bird species.

\section{Discussion:}

The potential for spread of infectious agents from wild birds and animals to human and domestic livestock is great, and this prospect is even more pronounced for wild birds. Many birds' species play an important role in faecal contamination of drinking water sources and agricultural crops and may also come into close contact with domestic birds enabling direct 
transfer of infectious agents to take place (Lillehaug et al, 2005).

Myint et al (2006) used the Buffer peptone water for Salmonella isolation followed by Rappaport Vassiliadis medium and tetrathionate broth.

The incidence of Salmonella species isolation from migratory birds was $28.26 \%$ (13/46). While, it was $4.96 \%$ (6/121) from Zoo birds, and by examination of free living birds (feral birds), the incidence of Salmonella was $18.57 \%$ (13/70).

These results are nearly in agreement with that obtained by Faddoul et al (1965) who surveyed wild birds and isolated Salmonella from 12 out of 100 samples. Eight of this isolates were from Cowbird, 2 from House sparrow, 1 from each of White throated sparrows and Herring gull with an incidence of $12 \%$. Cizek et al (1995) isolated Salmonella from 8 birds out of the 31 examined birds with an incidence of $25.8 \%$.On various agricultural farms, Salmonella were found in 2 birds out of 2186 birds examined. Out of 35 birds caught at a municipal waste-dump site, Salmonellae spp. were isolated from one specimen. While, none of Salmonella spp. were found in birds living in reed growths.

Also Mirzaie et al (2010) reported that from 470 house sparrows that were subjected to culture, the results showed that 18 samples (3.8\%) were positive for Salmonella. The 18 Salmonella isolates that were characterized showed that the most predominant serovars were Salmonella Typhimurium and $S$. enteritidis (9 and 8 cases each, respectively), whereas only 1 serovar belonged to $S$. Montevideo.

Different species of migratory birds were examined for Salmonella in our Reference laboratory for veterinary quality control on poultry production. On examination of 46 samples related to 8 species of live and dead migratory birds, only 13 samples were positive with a percentage of $28.26 \%$. (Table 2). It was revealed that Green winged duck had the highest percentage of isolation (77.78\%), and then Common pintail (75\%) and Sheldrake $(50 \%)$. On the other hand, Water fowl had the lowest percentage $(10 \%)$.

Nielsen (1960) detected an outbreak of salmonellosis in Mallard duck raised for hunting and concluded that they acquired infection from other wild birds. While, in 1999, Pennycott and Duncan reported an outbreak of salmonellosis in wild ducks and gulls in Northern Hemisphere.

On examination of 477 wild ducks by Mitchell and Ridgwell (1971), 20 ones were positive for Salmonella with a percentage of 4.11\%. While, Muller (1965) detected Salmonella in an incidence of $16 \%$ of wild duck feces. In Egypt, Abd El Aziz et al (2002) reported that after bacteriological examination of migratory ducks different bacteria were isolated and 
the numbers of positive samples for Salmonella were 6 from 120 with incidence $5 \%$.

Literak and Kraml (1985) suggested that laughing Gull can be considered as a possible source of Salmonella for farm animal stocks particularly Water fowl. Refsum et al (2002) revealed postmortem lesions of Salmonella in wild-living birds in Norway with the laboratory-confirmed findings of Salmonella which was isolated from 470 birds belonging to 26 species. The Salmonella-positive birds included 441 small passerines, 15 Gulls, 5 Water fowl, 4 birds of prey, 3 Doves, and 2 Crows. Many authors examined the same species of Zoo wild birds and isolated Salmonella from them as MacDonald (1965) who isolated Salmonella serotype Typhimurium 19 times. Friend and Franson (1988) reported salmonellosis in different species, such as Grouse, Pheasants and several species of Ducks.

Many researchers examined freeranging birds and isolated Salmonella as Brittingham and Temple (1986); Hilton et al (1997), and Pennycott and Duncan (1999) who isolated Salmonella from wild free living Pigeons and Sparrows in a garden, and Hudson et al (2000) who isolated Salmonella from free living Pigeons.

Also the present study supported the results obtained by Daoust et al (2000) who investigated 73 cases of
Salmonella from the dead several species of Song birds.

Salmonella Typhimurium was the most isolated strain (13/32) with a percentage of $40.6 \%$. These results are nearly close to Kirkpatrick and Colvin (1986), and Kirkpatrick and Trexler- Myren (1986) who reported that the most isolated serotype was Salmonella Typhimurium which was isolated from Kestrel, as well as Bowes (1993), Kirk et al. (2002) and Refsum et al (2002) who recorded that $S$. Typhimurium was recovered from all cases of wild birds examined from the period from 1969 to 2000.

Multiple antimicrobial resistant serotypes of Salmonella were usually isolated from both humans and animals at an increasing and alarming rate (Kirkpatrick and Colvin, 1986).

The control of Salmonella antibiotic therapy may aid in overcoming an outbreak (Stroud and Friend, 1987). And antibiotic therapy should be based on results of susceptibility testing (Quinn et al, 2002). The same result was reported by NCCLS (2000) who recommended that only ampicillin, quinolone and trimethoprim+ sulfamethoxazole should be tested and reported for the Salmonella. Monitoring programs are needed to detect these resistant strains before they become widely distributed.

Nagaraja et al (1991) mentioned several serological tests for 
detecting antibodies for Salmonellae.

Many researchers proved that the standard methods for isolation of Salmonella and other bacteria require several days up to 7 as Wilde et al (1990) and Andrew and Hannack (2003). While, PCR method targets specific segment of DNA that could be detected with minute quantities of DNA. (Hasan et al, 1991and Cohen et al, 1994), and with different or contaminated samples as Naguyen et al (1994).

Soumet et al (1997); Li et al (2000); Scholz et al. (2001) and Myint et al (2006) proved that the high sensitivity and specificity of PCR needs about 16- $24 \mathrm{hr}$.

Many authors as Tuchili et al (1995) and Drawin and Miller (1999) selected the invA and explained that this gene was necessary for the invasion to the cell. Although, Lampel et al (2000); Ferretti et al (2001); Liu et al (2002) and Salehi et al (2005) supported the use of invA primer due to its accuracy and uniform distribution.

RV enrichment resulted in great PCR sensitivity than non selective enrichment BPW. These results were corborated with Carli et al (2001); Olivera et al (2002); Olivera et al (2003); Freschi et al (2005) and Myint et al (2006). The present results didn't corborate the finding that RV medium was inhibitory to PCR as reported by Stone et al (1994), Soumet et al (1997). But, other researchers as
Schrank et al (2001) who combined PCR with MKTT and found that this medium was more sensitive than SC medium. But, Gunaydin et al (2007) proved that MKTT was more superior to $\mathrm{RV}$. These results might be due to the using of capillary PCR. While, in the present study, single conventional PCR was used. Also, Olivera et al (2003) reported that RV- PCR was more superior to SMT.

\section{Aknwoledgement:}

Many thanks for Dr. Abdullah Selim and Dr. Sayed Abdel Wahab (Reference Iab for Vet. Quality Control on Poultry Production).

\section{References}

Abd El Aziz, S.; Ragheb, S. and ElSheshtawy, E.A. (2002): Bacteria and parasites carried by migratory ducks in Damiatta and Port Said, Provinces, Egypt. J. Egypt Vet. Med. Assoc., 62(6): 257-266.

Andrew, W.H. and Hannack, T.S. (2003): Food and drug administration. Bacteriological analytical manual, chapter 5 .

Bowes, V.A. (1993): The 19921993 outbreak of salmonellosis in pine siskines in British Columbia. British Columbia Birds, 3 (1): 1316.

BrittIngham, M. C. and Temple, S.A. (1986): A survey of avian mortality at winter feeders. Widl. Soc. Bull., 14: 445-450.

Carli, K.T.; Unal, C.B.; Caner, V. and Eyigor, A. (2001): Detection of Salmonellae in chicken feces by a 
combination of tetrathionate broth enrichment, capillary PCR and capillary gel electrophoresis. J. Clin. Microbiol. 39: 1871-1876.

Cizek, A.; Literak, I.; Hejlicek, K.; Treml ,F. and Smola, J. (1995): Salmonella contamination of the environment and its incidence in wild birds. Zentralbl Veterinarmed, 42(2):128.

Cohen, N.D.; Mcgruder, E.D.; Neibergs, H.L.; Behle,R.W.; Wallis, D.E.; and Hargis, M.E. (1994) : Detection of Salmonella enteritidis in feces from poultry using booster polymerase chain reaction and oligonucleotide primers specific for all members of the genus Salmonella. Poult. Sci., 73(2): 354-357.

Croci, L.; Delibato, E.; Volpe, G.; De-Medici, D. and Pallesschi, G. (2004): Comparison of PCR, electrochemical, enzyme linked immunosorbent assays and the standerard culture method for detection of Salmonella in Meat prouducts. Appl. Environ. Microbiol., 70(3): 1393-1396.

Cruickshank, R.; Duguid, J.P.; Marmoin, B.P. and Swain, R.H.A. (1975):

Medical Microbiology. The practice of medical microbiology, Vol. 11, $121^{\text {st }}$ Ed. Churchill Livingstone. Edinburgh

Daoust, P.Y.; Busby, D.G.; Ferns, L.; Goltz, J.; McBurney, S.; Poppe, $C$. and Whitney, H. (2000): Salmonellosis in songbirds in the Canadian Atlantic provinces during winter-summer 1997-98. Can. Vet. J., 41: 54-59.

Drawin, K.H. and Miller, V.L. (1999): Molecular basis of the interaction of Salmonella with the intestinal mucosa. Clin. Microbiol. Rev., 12: 405-428.

Faddoul, G.P, Fellows, G.w. and Baird, J. (1965): A survey of the incidence of Salmonellae in wild birds. Avian Dis., 10: 89-94.

Ferretti, R.; Mannazzu, L.; Cocolin, L.; Comi, G. and Clement. (2001):

Twelve-hours PCR- based method for detection of Salmonella spp in food. Appl. Environ. Microbiol., 74: 977-978.

Freschi, C.R.; Silva Carvalho, L.O. and De Olivera, C.J. (2005): comparison of DNA extraction methods and selective enrichment brothes on the detection of Salmonella Typhimurium in swine feces by polymerase chain reaction (PCR). Brazilin J. Microbiol., 36: 363-367.

Friend, $M$. and Franson, J.C. (1988): Field manual of wild life diseases general procedures and diseases of birds. Chapter 9, page 99-109 The USGS- National Wild life Health center, USA.

Gunaydin, E.; Eyigor, A. and Carli, K.T. (2007): A capillary polymerase chain reaction for Salmonella detection from poultry meat. Lett. Appl. Microbiol., 44(1): 24-29.

Hasan, J.A.K.; Knight, I.T.; Tate, C.R.; Mallinson, E.T.; Miller, R.G.; Colwell, R.R. and Joseph, 
S.W. (1991): Evaluation of radiolabeled and colorimetric DNA probes in comparison with an antigen screening assay for the detection of Salmonella from poultry farms. Avian Dis. 35: 397402.

Hilton, A. C.; Banks, J.G. and Penn, C.W. (1997): Optimization of RAPD PCR for fingerprinting Salmonella. Lett. Appl. Microbiol., 24:243-248.

Hudson, C.R.; Quist, C.; Lee, M.D.; Keyes, K.; Dodson, S.V.; Morales, C.; Sanchez, S.; Whit. D.G. and Maurer, J. J. (2000): Genetic relatedness of Salmonella isolates from non domestic Birds in Southeastern United States. J. Clin. Microbiol., 38 (5): 1860-1865.

ISO 6579 (2002): Microbiology of food and animal feeding stuffs. Horizontal method for the detection of Salmonella spp. $4^{\text {th }}$ Ed: International Organization for Standardization.

Johnson, D.C.; David, M. and Goldsmith, $S$.

(1992):

Epizootiological investigation of an outbreak of pullorum disease inAn integrated broiler operation. Avian Dis. 36(3): 770-775.

Kauffmann, $F$. and DasKauffmann, W. (2001): Antigenic formulas of the Salmonella serovars, WHO co -oborating centre for reference and research on Salmonella. $8^{\text {th }}$ Ed, cited by Popoff, M.Y., Paris, France.

Kirk, K.J.; Holmberg, C.A. and Jeffrey, J.S. (2002): Prevalence of Salmonella spp in selected birds captured on California dairies. J. Am. Vet. Med. Assoc., 220(3): 359362.

Kirkpatrick, C.E. and Colvin, B.A. (1986): Salmonella spp. in nestling common barn- Owls (Tytoalba) from southwestern New Jersey. J. Wildl. Dis., 22(3): 340-343.

Kirkpatrick, C.E. and TrexlerMyren, V.P. (1986): A survey of free-living falcon -form birds for Salmonella. J. Am. Vet. Med. Assoc., 189: 997-998.

Lampel, K.A.; Orlandi, P.A. and Kornegy, L. (2000): Improved template preparation for PCRbased assay for detection of foodborne bacterial pathogens. Appl. Environ. Microbiol., 66: 45394542.

Li, X.; Boudjellab, N. and Zhao, X. (2000): Combined PCR and dot blot assay for detection of Salmonella and listeria monocytogenes. Int. J. Food Microbiol., 56: 176-177.

Lillehaug, A.; Jonassen, C.M.; BergsjQ, B.; Hofshagen, M.; Tharaldsen, J.; Nesse, L.L. and Handeland, $K$. (2005): Screening of feral pigeon (Columba livia), Mallard (Anasplatyrhynchos) and graylag Goose (Anseranser) populations for Campylobacter spp., Salmonella Spp., Avian influenza virus and avian paramyxovirus. Acta Vet. Scand., 46(4): 193-202.

Literak, I. and Kraml, F. (1985): The occurrence of Salmonellae in wild birds (Passeriformes, Lariformes). Vet. Med. (Praha), 30(6): 353-358. 
Liu, T.; Liljebjelke, K.; Bartlett, E.; Hofacre, C.; Sanchez, S. and Maurer, J.J. (2002): Application of nested polymerase reaction for detection of Salmonella in poultry environment. J. Food Prot., 65(8): 1227-1232.

MacDonald,

J.W.

(1965):

Mortality in wild birds. Bird study, 12: $181-188$

Mitchell, T.R. and Ridgwell, T. (1971): The frequency of Salmonellae in wild ducks. J. Med. Microbiol., 4: 359-361.

Mirzaie, S.; Hassanzdehi, M. and Ashrafi,I. (2010): Identiication and characterization of Salmonella isolates from captured house sparrows. Turk. J. Vet. Anim. Sci. 34(2): 181-186.

Muller,G. (1965) : Salmonella in bird feces. Nature, 207: 1315.

Myint, M.S.; Johnson, Y.J.; Tablante, N.L., and Heckert, R.A. (2006): The effect of preenrichment protocol on sensitivity and specificity of PCR for detection of naturally contaminated Salmonella in raw poultry compared to conventional culture. Food Microbiol., 23: 599-604.

Nagaraja, K.V.; Pomeroy, B.S. and Williams, J.E. (1991): Paratyphoid infections. In: Calnek, B.W.; Barnes, H.J.; Beard, C.W.; Reid, W.M. and Yoder, H.W. jr. Diseases of poultry, $9^{\text {th }} \mathrm{Ed}$. Iowa state University press, Ames, Iowa. pp. 99-130.

Naguyen, A.V.; Khan, M.I., and Lu, Z. (1994): Amplification of Salmonella chromosomal DNA using the polymerase chain reaction. Avian Dis., 38: 119-126.

National committee for clinical standerd (NCCLS). (2000): Mic testing, NCCLS document M100S10 Wayne

Nielsen, B.B. (1960): Salmonella Typhimurium carriers in seagulls and mallards as a possible source of infection to domestic animals. Nord. Vet. Med., 12: 417-424.

OIE (2004): Salmonellosis in Manual of diagnostic tests and vaccines for Terrestrial animals. $5^{\text {th }}$ Ed (Chapter 3).

Olivera, S.D.; Rodenbusch, C.R.; Ce, M.C.; Rocha, S.L.S. and Canal, C.W. (2003): Evaluation of selective and non selective enrichment PCR procedures for Salmonella detection. Lett. Appl. Microbiol., 36: 217-221.

Olivera, S.D.; Santos, L.R.; Schuch, D.M.T.; Silva, A.B.; Salle, C.T. and Canal, C.W. (2002): Detection and identification of Salmonella from poultry related sampled by PCR. Vet. Microbiol., 87: 23-35.

Olivera, W.F.; Caroso, W.M.; Salles, R.P.R.; Teixeira, R.S.C.; Camara, S.R.; siqueira, A.A. and Marques, L.C.L. (2006): Initial identification and sensitivity to antimicrobial agents of Salmonella spp. Isolated from poultry products in the state of Ceara, Brazil. Barazillian J. Poult. Sci., 8(3): 193199.

Pennycott, T.W. and Duncan, G. (1999): Salmonella pullorum in common 
(phasianuscolchicus). Vet. Rec., 144(11): 283-287.

Quinn, P.J.; Carter, M.E.; Markey, B.K.; Donnoly, W.J. and Leonard, F.C. (2002): Veterinary microbiology and microbial disease 166-1117 Osney Mead, Oxford first LTd, Registered at the United Kingdom.

Refsum, T.; Handeland, K.; Baggesen, D.L.; Holstad, G. and Kapperud, G. (2002): Salmonellae in avian wildlife in Norway from 1969 to 2000. Appl. Environ. Microbiol., 68(11): 5595-5599.

Salehi, T.Z.; Mahzounieh, M. and Saeedzadeh, A. (2005): Detection of invA Gene in isolated Salmonella from broilers by PCR method. Int. J. Poult. Sci., 4(8): 557-559.

Scholz, H.C.; Arnold, T.; Marg, H.; Rosler, U. and Hensel, A. (2001): Improvement of an invAbased PCR for the specific detection of Salmonella Typhimurium in organs of pigs. Berl. Münch. Tieräztl. Wschr., 114: 401-403.

Schrank, I. S.; Mores, M. A. Z.; Costa, J. L. A.; Frazzon, A. P. G.; Soncini, R.; Schrank, A.; Vainstein, M. H. and Silva, S. C. (2001): Influence of enrichment media and application of a PCR based method to detect Salmonella in poultry industry products and clinical samples. Vet. Microbiol., 82: 45-53.

Soumet, C.; Ermel, G.; Salvat, G. and Colin, P. (1997): Detection of Salmonella spp in food products by polymerase chain reaction and hybridization assay in microplate format. Lett. appl. Microbiol., 24(2): 113-116.

Stone, G.G.; Oberst, R.D.; Hays, M.P.; McVey, S. and Chengappa, M.M. (1994): Detection of Salmonella serovars from clinical samples by using enrichment broth cultivation - polymerase chain reaction procedure. J. Clin. Microbiol., 32: 1742-1749.

Stroud, R.K.; Friend, M. (1987): Avian salmonellosis. In: Friend, M.; Laitman, C.J.; eds. Field Guide to Wild life diseases. Vol 1. General Field procedures and diseases of migratory birds. Washington, DC: US Department of the Interior, Fish and Wildlife Service: 101-106.

Swayne, D.E.; Gilsson, J. R.; Jackwood, M.W.; Pearson, J.E. and Reed, W.M. (1998): A laboratory manual for the isolation and identification of avian pathogens, $4^{\text {th }}$ Ed., American association of Avian Pathologists University of Pennsylvania New Bolton Center.

Tuchili, L.M.; Kodama, H.; Izumoto, Y.; Mukamoto, M.; Fukata, T.; Baba, T. (1995): Detection of Salmonella Gallinarum and Salmonella Typhimurium DNA in experimentally infected chicks by polymerase chain reaction. J. Vet. Med. Sci., 57(1): 59-63.

Wilde, J.; Eiden, J. and Yolken, $R$. (1990): Removal of inhibitory substances from faecal specimens for detection of group A rotaviruses by reverse transcriptase and polymerase chain reaction, J. Clin. Microbiol., 28: 1300-1307. 


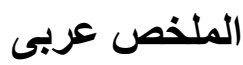

\section{التقصى عن السالمونيلا في الطيورالمهاجرة و الحرة و طيور حئيو حديقة الحيوانات

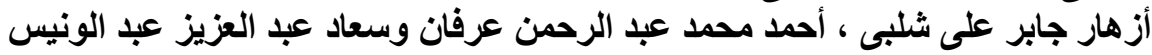

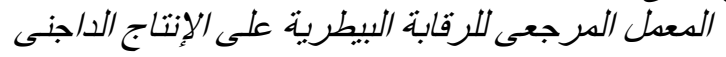

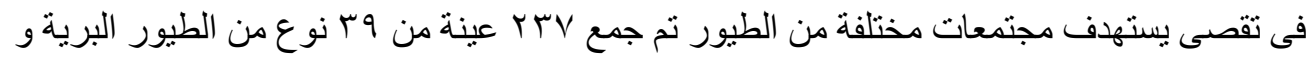

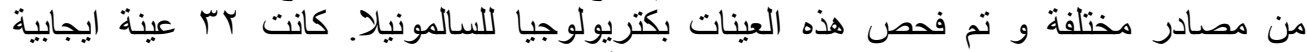

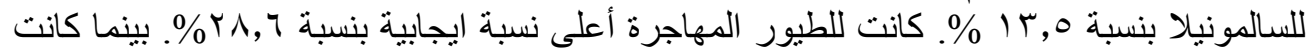

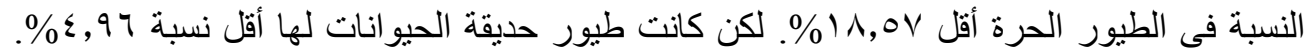

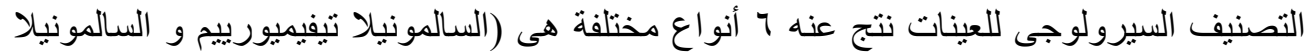

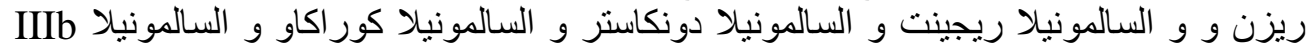

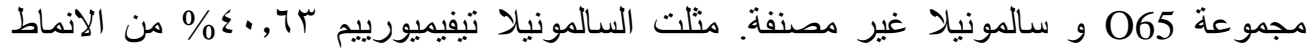

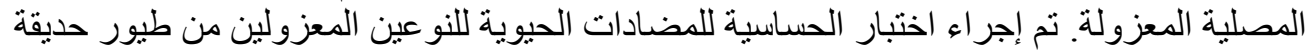

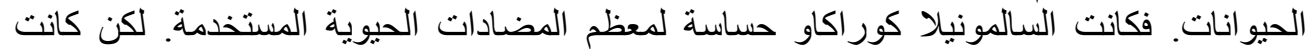

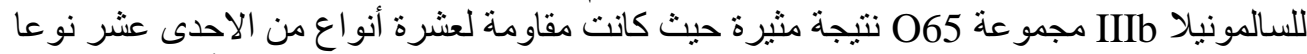

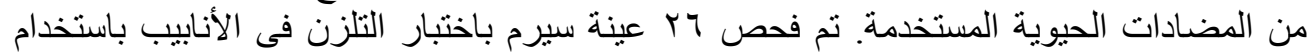

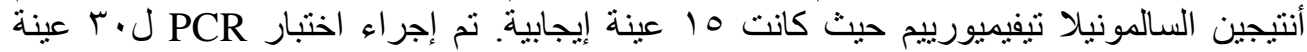

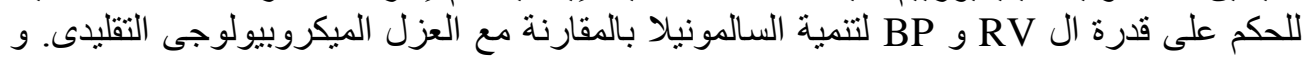

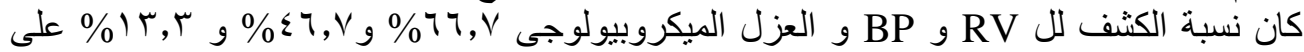

